\title{
Quality Determinants of Independent Audits of Banks
}

José Alves Dantas

Adjunct Professor, Department of Accounting and Actuarial Sciences, University of Brasília

E-mail: josealvesdantas@unb.br

\section{Otavio Ribeiro de Medeiros}

Full Professor, Department of Accounting and Actuarial Sciences, University of Brasília

E-mail: otavio@unb.br

\section{ABSTRACT}

Since DeAngelos study (1981) on audit quality, the latter has been a topic well discussed in the international accounting literature; however, there is little evidence about audit quality in the financial market. In Brazil, studies on audit quality began only in the 2000s, although without a specific focus on banks. The purpose of this study was to identify the quality determinants of audit work in Brazilian banking institutions. Using the practice of earnings management as a proxy for audit quality - more specifically, the discretionary accruals related to the process of the constitution of the Loan Loss Provision (LLP).- tests were performed based on the quarterly information of commercial and multipleservice banks and savings banks from 2001 to 2012. Empirical tests have shown that the quality of audit work has several types of relationships as follows: negative with the client importance level for the auditor; negative with the works after the sixth year of the contract; positive with the establishment of the Audit Committee by the banks; positive with the judgment of punitive administrative proceedings against independent auditors; and positive with the level of rigor of the regulatory environment. Of the tested hypotheses, three were not confirmed empirically. The first hypothesis predicted an association between audit quality and the auditor degree of specialization in the banking industry. The second hypothesis predicted that audit quality would be negatively correlated with the degree of concentration of audit activity within the National Financial System (Sistema Financeiro Nacional - SFN). The third hypothesis predicted that audit quality would be lower when the auditorclient relationship is of a short term. The results of the study contribute to the debate concerning the role of auditors in the transparency and solidity of the financial system, including their role as a complementary or auxiliary supervisor.

Keywords: Audit. Quality. Manipulation. Discretion. Banks. 


\section{INTRODUCTION}

The performance of independent auditors is deemed fundamental to the functioning of the financial and capital markets based on the assumption that, by issuing an opinion on the reliability of accounting information, it contributes to a business environment characterized by trust and credibility (Newman, Patterson \& Smith, 2005; Ojo, 2008; Basel Committee on Banking Supervision [BCBS], 2008; Zagonov, 2011). However, with the corporate scandals at the start of the century, characterized by fraud and accounting manipulation, much has been discussed about the scope of responsibilities of auditors, given that opinion on financial statements has not changed.

The most important reaction to these scandals was the enactment, in the United States (USA), of the Sarbanes-Oxley Act, which reduced the self-regulation power of auditors, creating the Public Company Accounting Oversight Board (PCAOB) with the task of regulating the profession, setting norms and enforcing professional discipline (Coffee, 2004).

The first large test of this regulatory framework was the global financial crisis of 2008, when auditors were questioned for not anticipating the banking problems. In the assessments of the determinants of the crisis, the supervising authorities strongly questioned the role of auditors, and cited a "worrying lack of skepticism" of the profession (Sanderson, 2010). In the case of the crash of Lehman Brothers, for example, investigation reports indicate that the institution manipulated financial reports using accounting artifices to hide debts, the reason why Ernst \& Young (E\&Y) was accused of serious mistakes that contributed to what had happened (BBC Brazil, 2010).

Concerns regarding the occurrence of audit failures in the banking system are discussed by the Basel Committee on Banking Supervision (BCBS, 2008), which highlighted the need for greater confidence by bank supervisors regarding the audited information and character of large audit companies, due to issues such as the increasing complexity of accounting norms and financial instruments, as well as changes associated with the estimation of the fair value.

This concern by bank supervisors is justified, particularly because the performance of independent auditors has a direct relationship with the purpose of ensuring the credibility of the financial reporting process, and the reliability of financial reporting is an essential condition for the functioning of the banking system, as financial institutions are exposed to the risk of "bank run" in the case of suspicion by depositors. In summary, there is an objective link between the mission of auditors to ensure the reliability of the information and stability of the banking system, given their significant impact on the national economy.

The importance of studies on audit quality in the financial system, particularly in Brazil, can be exemplified by that among the most emblematic cases of audit failures discussed in the national media are the cases of fraud committed by banks, such as the cases of the Nacional, Noroeste and Panamericano banks, which resulted in questions relating to their auditors - KPMG, PWC and Deloitte, respectively.

Notwithstanding this situation and the ample space that the issue of audit quality has garnered in the international accounting literature since DeAngelo's study (1981), there is little evidence of studies that deal specifically with audit quality in the financial market, as noted by Kanagaretnam, Lim and Lobo (2010) and Zagonov (2011). In Brazil, starting only in the late 2000s, studies concerning audit quality ${ }^{1}$ began to be conducted, but with a specific focus on banking institutions; Santos (2008) seems to be an exception.

Given this context, the present study aims to identify the quality determinants ${ }^{2}$ of the works undertaken by independent auditors at banking institutions of the National Financial System (Sistema Financeiro Nacional - SFN). By contributing to a better understanding of audit work in the banking environment, and filling a gap in the literature in this regard, the present study is supported by the precepts of the Basel Committee (BCBS, 2008) that the complexity of the financial market and demand for an increase in transparency suggest that clear and reliable accounting information, supported by quality audits, is essential to increase market confidence.

To conduct empirical tests, the present study uses data from the Quarterly Financial Information of commercial, multiple-service and savings banks, available on the website of the Central Bank of Brazil (Banco Central do Brasil BCB), considering the period 2001-2012.

\section{THEORETICAL FRAMEWORK}

\subsection{Audit Quality - Measurement.}

As discussed, a quality audit is an essential tool for the functioning of the financial and capital markets, contributing to an environment of confidence and credibility. However, what is a quality audit, and how is it measu- red? According to Manita (2009), that the audit process is complex (non-uniform) and not observable by third parties and that the report (opinion) is standardized, with few possibilities for differentiation hamper the identification of a quality audit. 
According to Dye (1993), audit quality is not information disclosed at the time it is performed, and even $a$ posteriori, it is not made public for cases of clients who do not face financial difficulties, considering that there will be no reason or evidence for questioning the auditors' work. Reinforcing this understanding, Pae and Yoo (2001) emphasize that the auditor is questioned only when (i) the statement prepared by management is distorted; (ii) the auditor provides a positive opinion on these distorted information; (iii) the investor, relying on this information, makes a decision to invest in the company; and (iv) the expected return is not confirmed. Only when these four conditions are observed is the auditor questioned.

This difficulty in measuring audit quality is reinforced by the statement of the BCBS (2008) that there are no tools to objectively measure audit quality, despite the continued efforts in this direction. The concern about the parameters for assessing audit quality can also be extracted from the conclusions of the United States Treasury Department's Advisory Committee on the Auditing Profession (ACAP), established to formulate suggestions for strengthening audits. One of the recommendations is for the PCAOB to develop and monitor key indicators of audit quality (Carcello, Bedard, \& Hermanson, 2009).

With this objective difficulty (or even impossibility) of simultaneously measuring and verifying audit quality, studies evaluating this issue need to use proxies, based on some information from the audit process (the few available ones), for market variables and accounting information.

\section{2 "Real" Quality versus "Perceived" Quality.}

Dang (2004) classifies the proxies for audit quality metrics into two groups: those that seek to reflect the "actual" audit quality and those summarizing the audit quality "perceived" by the market.

It should be emphasized that "actual quality" cannot be understood as an absolute. The term is used because quality is measured from ex post information, indicative of proble$\mathrm{ms}$ in relation to statements such as: restatement determinations by the regulator, as in Dang (2004) and Braunbeck (2010); voluntary restatement as in Dang (2004); litigation against the auditor arising from lawsuits or administrative penalties, as in Palmrose (1988) and Braunbeck (2010); and finding material distortions in financial statements without a modified opinion in the auditor's report, as in Geiger and Raghunandan (2002).

The premise for using these variables in the estimation of audit quality is that the very occurrence of these factors would be evidence that the auditor did not fulfill his role properly. Although these ex post measures represent audit problems more objectively, they also have limitations. The first is that they fail to capture evidence that serves to simultaneously estimate the quality of the audit. The second is that, even a posteriori, they cannot capture all the possible problems of low-quality audits - materially-distorted statements, if not discovered by regulatory bodies, are treated as evidence of a high-quality audit. The third limitation is that the same audit can be treated as high or low quali- ty, depending on the time when the study was conducted - whether before or after a restatement or litigation. The fourth is that it is not always possible to identify the cause and effect relationship in these measures; a restatement decision, for example, may be due to an auditor's caveat - i.e., the auditor's performance is what may have induced the regulator's action.

Although several studies have sought to measure "actual" audit quality, what has prevailed in the literature, since DeAngelo's study (1981), are the metrics that try to capture "perceived" audit quality, such as: (i) the auditor's size, particularly big- $N$, as in DeAngelo (1981), Teoh and Wong (1993), Dang (2004), Gu, Lee and Rosett (2005), Behn, Choi and Kang (2008), Kanagaretnam, Krishnan and Lobo (2009, 2010), and Zagonov (2011); (ii) auditor specialization, as in Behn et al. (2008), Chambers and Payne (2008), Romanus, Maher and Fleming (2008) and Kanagaretnam, Krishnan et al. (2009, 2010); (iii) coefficient of the response of the stock price to the accounting results, as in Teoh and Wong (1993) and Ghosh and Moon (2005); and (iv) errors in the projections of managers or analysts, as in Dang (2004) and Behn et al. (2008).

Despite the large number of studies with these proxies, particularly those that use the dichotomous variable big- $N$, the debate continues on their ability to capture the actual audit quality. Dang (2004) argues that audit failures revealed in cases such as those of Enron, Waste Management and WorldCom cast doubt on the positive relationship between audit firm size and quality. Another problem is that, by using dichotomous variables as proxies for audit quality, according to Dang (2004), two problematic assumptions are made: the first one is that the audit firm would perform audits for different clients and at different periods of time, with the same quality level; the second is that the quality of a group of auditors - big- $N$ or non-big- $N$, for example would be homogeneous.

\subsection{Auditor Quality versus Audit Quality.}

The issue concerning how to address quality proxies leads to another discussion in the literature on the topic: the quality of audit firms versus the quality of audit services. When DeAngelo (1981) defines audit quality as the probability perceived by the market that a given auditor will detect material distortions (technical expertise) in the client's statements and that the auditor will report such problems (independence to give opinion), the focus is obviously on the auditor.

The problem is that this assumption ignores that each audit has its own reality, being influenced by the characteristics of the business, management profile, governance structure, economic conditions, and auditor-client relationship, among other factors. Lam and Chang (1994), for example, argue that audit quality must be defined at each service, given that a firm cannot carry out all of its audits to the same quality level. According to this understanding, auditor quality is distinguished from the quality of the audit services; in the present study, this second criterion will be adopted. 


\subsection{Information Quality - Audit Quality.}

If there is no consensus in the literature regarding the measure used as a proxy for audit quality, it is reasonable to state that audit quality should be linked to the quality of the statements. This is because any material distortions in the information produced by management would be previously fixed by the action of auditors. Therefore, one would assume that a measure that measures the quality of accounting information also reflects the quality of the audit.

In this regard, a measure widely used as a benchmark for audit quality is to identify the practice of earnings management - more specifically, through discretionary accruals. It integrates the set of the most listed measures in the literature on audit quality, along with the auditor's size and expertise (Gul, Fung \& Bikki, 2009). According to Braunbeck (2010), studies examining the quality of audits based on the quality of accounting information consider an intuitive reasoning: the better the quality of the audit, the higher the quality of the information disclosed.

The use of this proxy of audit quality is based on the premise that the auditor is responsible for ensuring a true, fair and neutral financial disclosure, avoiding opportunistic manipulation by management. Among the studies that used this variable somehow in the analysis of audit quality, the following can be cited: Heninger (2001), Government Accountability Office - GAO (2003, 2008), Dang (2004), Venkataraman, Weber, and Willemborg (2008), Chambers and Payne (2008), Kanagaretnam, Krishnan et al. (2009, 2010), Silva and Bezerra (2010), Kanagaretnam, Lim et al. (2010), and Siregar, Amarullah, Wibowo and Anggraita (2012).

Heninger (2001) advocates the use of earnings management as a proxy for audit quality because this practice compromises the quality of financial disclosure, which has been worrying regulators. Kallapur, Sankaraguruswamy and Zang (2010) reinforce this understanding, arguing that it allows for a more comprehensive analysis of the problem, not limited to exceptional situations, such as cases of restatements or ongoing problems. Dang (2004) combines both measures, claiming that high-quality audits increase the possibility of detecting and preventing the practice of earnings management. According to this logic, if accounting profits deriving from earnings management are seen as lower quality, then those auditors who do not detect and act to mitigate this practice should be seen as lower quality auditors. Evidence of the association between these phenomena can be inferred from the finding that auditors intensify efforts and increase the price charged for their services when they identify evidence of accounting manipulation risk (Bedard \& Johnstone, 2004).

Heninger (2001), without classifying earnings management as fraud, notes that this practice is a direct intervention in financial disclosure, with the intent of gaining advantage for specific agents, rather than a neutral mechanism of disclosure. In this sense, agents interested in accounting information expect auditors to limit this practice and reinforce fair and true financial disclosure. If the manager inflates the results to hide unfavorable information, and the auditor does not mitigate this manipulation, then the financial reports do not provide warning of potential problems.

Finally, another aspect to be highlighted to demonstrate the relevance of quality measurements of financial information for estimating audit quality is that even studies using measures such as the size of the audit company (big- $N$ ) or auditor specialization as proxies of quality adopt a standard procedure to test the relationship between these measures and the level of discretionary accruals when they need to confirm the validity of these metrics. This was the case, for example, for Kanagaretnam, Krishnan et al. (2009, 2010) and Martinez and Reis (2010), among others.

\subsection{Auditors' Responses to Earnings Management.}

Considering earnings management as a non-neutral financial disclosure resulting from an intentional intervention of managers to produce some private gain (Schipper, 1989), associated with the precept that the auditor is responsible for acting on the assumption of ensuring non misleading disclosure, it becomes evident that this professional is accountable for acting to restrict/limit the actions that may be characterized as manipulative of the actual economic-financial situation of the company.

This understanding of the role of auditors as agents mitigating the discretionary action of management on financial disclosure is reinforced, among others, by Vincent et al. (2003) and Kanagaretnam, Lim et al. (2010).

Dang (2004) summarizes the relationship between audit and earnings management by stating that the role of the auditor is to mitigate the information asymmetry between the parties, which is why audit quality should be related to lower levels of asymmetry and uncertainty regarding the performance of the entity. Thus, the author concludes, audit quality should be negatively related to earnings management.

\section{DEVELOPMENT OF RESEARCH HYPOTHESES}

\subsection{Auditor Specialization.}

Using the assumption that knowledge concerning the client and his business increases the auditor's ability to identify potential material distortion, authors such as Behn et al. (2008) and Romanus et al. (2008) use the level of spe- cialization in the industry as a proxy for audit quality. It is expected that the greater is the relevance of the economic segment to the auditor, the greater is their ability to provide quality services, considering their greater expertise in that type of business. 
This understanding is reinforced by Gul, Fung and Bikki (2009) and Chambers and Payne (2008), in stating that auditor specialization in a given industry leads them to have a broader understanding of accounting practices and trends in the segment, increasing their ability to evaluate evidence and identify problems in the statements. The results found by Carcello and Nagy (2004) and Krishnan (2005) also indicate that auditor specialization is an element that enhances the quality of financial disclosure and mitigates the probability of fraudulent statements.

Particularly, regarding the banking industry, Kanagaretnam, Lim et al. (2010) emphasize that auditors who are experts in the banking industry can assess more appropriately the suitability of the information produced by management. An example of this relationship is given by Kanagaretnam, Krishnan et al. (2009) who, when examining the role of auditor reputation on audit quality perceived by the market, found a positive association between the discretion of the Loan Loss Provision (LLP) with the stock returns of banks audited by companies with greater expertise in the banking industry.

Given the above, the following research hypothesis is formulated:

$\mathrm{H}_{1}$ : The quality of audits conducted in Brazilian banks is positively related to the degree of auditor specialization in the industry.

\subsection{Importance of the Client for the Auditor Portfolio.}

Another aspect that can influence audit quality derives from the affirmation of Murcia and Borba (2007) that the conflict of interest in the relationship between the auditor and audited company, which hires and pays the auditor, can influence, in some cases, the content of the report (opinion). Nelson, Elliott and Tarpley (2002) address this issue by noting that the requirement to maintain and expand businesses and client relationships may compromise objectivity and professional independence. The marketing issue is also highlighted by Coffee (2004) as a reason for the auditors, in certain situations and under certain conditions, to agree with the client, taking on the cost of any lawsuit losses and risk of some public humiliation.

One aspect that may explain this behavior, though not justifiable, is the degree of importance of the client to the audit firm, making the firm more compromising with the client's demands. This perception is highlighted by DeAngelo (1981), Chambers and Payne (2008) and Amir, Guan and Livne (2010), in stating that the economic dependence between auditors and their clients may increase when one of these clients accounts for a relevant portion of the auditor's income and may influence the independence and professional skepticism of the latter.

This concern is consistent with the evidence gathered by Nelson et al. (2002) from reports of earnings management attempts experienced by 253 auditors of the big five. Among the findings, it was found that auditors are more likely to require adjustments of these attempts when they are attempted by smaller clients, indicating that the importance of the client interferes with the auditor's stance.
Specifically addressing bank audits, Ojo (2006) reinforces this understanding by emphasizing that the possibility of compromising lucrative contracts may lead the auditor to think twice before issuing an opinion adverse to the interests of the institution.

Considering this context, the following research hypothesis is formulated:

$\mathrm{H}_{2}$ : The quality of audits conducted in Brazilian banks is negatively related with the level of importance of the client to the audit firm.

\subsection{Length of Contract between the Auditor and Financial Institution.}

By relating the issue of professional skepticism to audit quality, Lys and Watts (1994) argue that long-term auditor-client relationships tend to reduce professional independence, which should be reflected in the quality of the audit. The interaction between auditor and client is also underlined by Demski (2004) as one of the elements that may be important in the performance of the audit work. To prevent such situations, the idea of a mandatory rotation of auditors has been discussed, the purpose of which would be, according to Nagy (2005), to limit the relationship between auditors and clients, assuming that when this relationship lasts a long time, professional independence could be compromised.

Siregar et al. (2012), however, note distinct nuances in relation to audit tenure. For them, the early years of contracts may be perceived as less effective, considering it takes time to evaluate audit risks, whereas maintaining the contract for a long period of time may compromise professional skepticism. Due to this duality, several studies have tested the relationship between audit tenure and audit quality, without homogeneous results. As an example, Ghosh and Moon (2005) found a positive relationship between the length of the auditor-client contract and audit quality, defined by the response coefficient of return-earnings regressions, while Dao, Mishra and Raghunandan (2008) found an inverse relationship between audit tenure and the ratification of auditors by shareholders, indicating that shareholders see the long length of relationships as an element that negatively affects the quality of the audit.

In the Brazilian market, some studies tested the impact of the quality of accounting information caused by the length of the auditor-client relationship, with a particular emphasis on the rotation of auditors - for example, Oliveira and Santos (2007), Santos (2008), Silva and Bezerra (2010) and Martinez and Reis (2010) - without finding consistent results regarding the expected pattern that may be representative of a conclusive opinion on the subject.

Given this duality, two research hypotheses are formulated:

$\mathrm{H}_{3 \mathrm{~A}}$ : The quality of audits conducted in Brazilian banks is negatively associated with the auditor-client short-term relationship.

$\mathrm{H}_{3 \mathrm{~B}}$ : The quality of audits conducted in Brazilian banks is negatively associated with the auditor-client long-term relationship. 


\subsection{Presence of the Audit Committee.}

Given the essential condition of independence for the quality of the auditors' works, an instrument that has been increasingly used, mainly since the Sarbanes-Oxley Act (SOX), in the sense of contributing for this independence to be effective, is the institution of the so-called audit committees. According to Borgeth (2007), the great purpose of creating the committee is to mitigate the risk of connivance between management and independent auditors.

In this context, despite concerns about the effectiveness and objectivity of the Audit Committee (Smith, 2006), including the method of compensation of its members that may create incentives to overvalue the company's shares or increase the profit (Magilke, Mayhew \& Pike, 2009), it is expected that the Committee's performance contributes to the quality of audits, strengthening the capacity related to implementing professional skepticism of the independent auditor. This provides support to the following research hypothesis:

$\mathrm{H}_{4}$ : The quality of audits conducted in Brazilian banks is positively related with the existence of an Audit Committee at the institution.

\subsection{Concentration of Audit Market.}

Although it is a historical characteristic, the concentration of the audit market has drawn the attention of the authorities. In the SOX, for example, it was determined that the Government Accountability Office (GAO) would study the implications of the consolidation of this market regarding competition, the client choice process, the remuneration charged by auditors and audit quality. The GAO (2003) concluded that although it found no evidence of restrictions on competition, relevant changes in the profession may have implications for competition and choice of companies. Regarding the quality of the audits conducted, no statistically significant relationship with the degree of concentration was found. Five years later, the GAO (2008) conducted another study in which the findings of the first one were repeated.

Regarding the impact of this concentration on the quality of audits, Ojo (2008) highlights that while some evidence supports that concentration encourages specialization, reducing the risk of distorted statements, other findings show that having a greater number of audit companies reduces the risk that a dominant company may establish practices encouraging low-quality financial statements. Kallapur et al. (2010), however, examined whether market concentration would undermine audit quality, finding a positive association between the increase of concentration and quality of accounting information, a proxy of audit quality.

In the present study, it is assumed that market concentration compromises the degree of auditor skepticism, considering the potential "accommodation" resulting from the lack of competition, with the following research hypothesis being formulated, to be tested empirically:

$\mathrm{H}_{5}$ : The quality of audits conducted in Brazilian banks is negatively related with the degree of concentration of the audit market in the sector.

\subsection{Litigation Risk.}

In the early 1990s, Dye (1993) highlighted that the audit market in the USA was experiencing strong transformations, including a major increase in lawsuits against auditors. Regarding this litigation risk, Ojo (2008) emphasizes that its effects may assume two forms. On the one hand, litigation risk may create economic incentives for auditors to reflect on the consequences of their actions, reducing the possibility of being indulgent in acts with negative consequences. On the other hand, it may increase the tendency to adopt a defensive audit - in which prescribed rules are interpreted, primarily by the exercise of subjective judgment.

The impact of litigation risk on the services provided by audit firms has been assessed over time, as exemplified in the studies by Dye (1993), Heninger (2001) and Talley (2006), acquiring more relevance with the problem of corporate scandals. This question is particularly important, given that, for the auditor, litigation risk is not only a financial issue but also a reputational one, affecting their credibility.

Thus, the following research hypothesis is formulated, to be tested empirically:

$\mathrm{H}_{6}$ : The quality of audits conducted in Brazilian banks is positively related with the increased risk of litigation against auditors.

\subsection{Rigor of the Regulatory Environment.}

According to DeFond, Wong and Li (1999), although not sufficient by themselves, it is expected that more rigorous norms, with more detailed procedures and assignments of responsibility forecasts, affect the behavior of auditors, making them less resilient to the clients' pressures for aggressive disclosures.

For Besacier, Hottegindre, and Fine-Falcy (2011), audit quality is the core of the latest regulatory movements. For them, from a practical point of view, the financial scandals of the early century, particularly involving Arthur Andersen, have demonstrated the inadequacy of the conceptual parameters that underpin audit quality based on the assumptions of independence and competence. For this reason, according to the authors, the regulations expanded the perception of audit quality, covering issues such as the auditor responsibility level, restrictions on consulting services, and characteristics and concentration of the audit market.

Most studies testing the relationship between the regulatory environment and audit quality concluded a preponderance of positive effects of regulation, including Cohen, Dey and Lys (2008), Silva and Robles Junior (2008), Amir, Guan, and Livne (2010), and Read and Feldmann (2010), providing support to the following research hypothesis:

$\mathrm{H}_{7}$ : The quality of the audits conducted in Brazilian banks is positively related with the level of rigor of the regulatory environment. 


\subsection{Model for Calculating the Audit Quality Proxy.}

Due to the reasons explained in Section 2, the audit quality proxy used in this study will be based on identifying the practice of earnings management - more specifically, discretionary accruals. The assumption is that opportunistic manipulation compromises the quality of the information and that the finding of this practice indicates that the auditor did not fulfill their mission of preserving the neutrality of the statements.

Despite the relevance of the logic implicit in this reasoning, it is important to emphasize some methodological limitations: (i) unusual non-discretionary factors may also influence abnormal accruals (Bernard \& Skinner, 1996); (ii) discretion by management in the production of information is not necessarily negative, when considering an informational component, which is the communication of private information of the entity (Kanagaretnam, Krishnan, \& Wolf, 2009; Kallapur, Sankaraguruswamy, \& Zang, 2010); and (iii) the reversal nature of accruals makes the assumption of a continuous, direct or inverse relationship of accruals with another variable untenable (Gu, Lee \& Rosett, 2005).

To address these limitations, the calculation of the proxy will not consider the discretionary accruals, but the difference between two periods in a row - the first difference, in absolute value, according to equation (4.1). Thus, rather than seeking to identify the level of discretionary accruals allowed by the auditors, whether the practice of accruals recognition is changed from one period to another is evaluated. This procedure is con- sistent with studies that argue for the persistence of accruals as the most appropriate parameter to assess its reliability, as in Chambers and Payne (2008). Finally, this difference is multiplied by $(-1)$ to adjust the metric to precept that, the higher the bias, the worse the audit quality will be. The use of the absolute value and multiplication by $(-1)$ to determine the audit quality proxy is inspired in Kallapur et al. (2010), with the difference that these authors did not work with the concept of the first difference.

$$
A Q_{i, t}=\left|D A c c_{i, t}-D A c c_{i, t-1}\right| *(-1)
$$

where: $A Q_{i, t}$ is quality of the audit performed in bank $i$ in period $t$ and $D A c c_{i, t}$ are the discretionary accruals that correspond the error term of the model (4.2).

The calculation of the variable $D A c c$, in turn, is based on the identification of discretion practiced in relation to the LLP, which is the area that recorded the highest number of studies on the practice of earnings management in banks. This concentration is justified by Kanagaretnam, Lobo and Mathieu (2003) because these allowances represent the largest accruals of banks, playing a key role in decisions by managers about possible accounting manipulations. According to Alali and Jaggi (2010), there is a widespread belief in the market that bank managers extensively use LLP to manipulate the results reported, which have been a focus of concern by regulators.

To identify this discretion, the model (4.2) developed by Dantas, Medeiros and Lustosa (2013) is used ${ }^{3}$ :

$$
\begin{aligned}
L L P_{i, t}= & \beta_{0}+\beta_{i}+\beta_{1} \Delta L O A N_{i, t}+\beta_{2} N P L_{i, t-1}+\beta_{3} \Delta N P L_{i, t}+\beta_{4} L C O_{i, t}+\beta_{5} L L A_{i, t-1}+\beta_{6} I N T_{i, t} \\
& +\beta_{7} G D P_{t}+\psi_{1}<T Y P_{i, t}>+\psi_{2}<G E O_{i, t}>+\psi_{3}<M A T_{i, t}>+\psi_{4}<C N C_{i, t}>+\varepsilon_{i, t}
\end{aligned}
$$

where:

$L L P_{\mathrm{i}, \mathrm{t}}$ : provision for loan losses of bank $i$ in period $t$;

$\triangle L O A N_{\mathrm{i}, \mathrm{t}}$ : change in the value of loans from period $t-1$ to $t$ of bank $i$;

$N P L_{\mathrm{i}, \mathrm{t}-1}$ : nonperforming loans in period $t-1$ of bank $i$;

$\triangle N P L_{\mathrm{i}, \mathrm{t}}:$ change in the value of nonperforming loans from pe-

riod $t-1$ to $x$ of bank $i$;

$L C O_{\mathrm{i}, \mathrm{t}}: \quad$ net loan write-offs of bank $i$ in period $t$;

$L L A_{\mathrm{i}, \mathrm{t}-\mathrm{i}}$ : loan loss allowance of bank $i$ in period $t-1$;

$I N T_{\mathrm{i}, t}: \quad$ average implicit interest rate of the loan portfolio of bank $i$ in period $t$, corresponding to the ratio between revenues from credit operations and the portfolio's average balance;

GDP: rate of change in Gross Domestic Product in basic prices, in period $t$;
$<T Y P_{\mathrm{i}, \mathrm{t}}>$ : vector of control variables representing the proportions of loans of bank $i$ in period $t$ distributed into public sector $(P U B)$, private sector (PRV) and non-residents (NRES); $<G E O_{\mathrm{i}, \mathrm{t}}>$ : vector of control variables representing the proportions of loans of bank $i$ in period $t$ located in the following geographic regions: Southeast $(S E)$, other regions of Brazil $(O R B)$ and overseas $(E X T)$;

$<M A T_{\mathrm{i}, \mathrm{t}}>$ : vector of control variables representing the proportions of loans of bank $i$ in period $t$ distributed according to the maturity of loans: up to 5 years (UP5Y), and exceeding 5 years $(E X 5 Y)$;

$<C N C_{i, t}>$ : vector of control variables representing the proportions of loans of bank $i$ in period $t$ distributed in the one hundred largest customers $(U P 1 H)$, and to other customers $(E X 1 H)$; and 
$\varepsilon_{i, t}$ is the error term, corresponding to the discretiorary portion of $L L P_{\mathrm{i}, \mathrm{t}}$ of bank $i$ in period $t$.

By adopting a common procedure in quantitative accounting studies, such as the one by Kanagaretnam, Lim et al. (2010), the variables $L L P, \triangle L O A N, N P L, \triangle N P L, L C O$ and $L L A$ are normalized by the total assets at the beginning of the period.

It is important to note that, although the tests are based on financial information produced by Brazilian banking institutions, prepared in accordance with the standards determined by the $\mathrm{BCB}$, which can be defined as rule-based, there is room for management discretion. Resolution 2,682 of the National Monetary Council (Conselho Monetário Nacional - CMN), of December 21, 1999, determines that loan operations should be classified in an order of increasing risk, with a ratio of allowance for losses for each risk level, in accordance with a scale ranging from $0 \%$ for risk level AA to $100 \%$ for risk level $\mathrm{H}$. As noted by Dantas et al. (2013), subjectivity derives from the criteria adopted by management to define this classification. There is guidance, for example, for banks to consider, among other factors, the economic sector to which corporate debtors belong, as well as aspects relating to the loan operations, such as the nature and purpose of the loan and the amount and characteristics of the guarantee. It should also be noted that institutions may make allowances at a level higher than the minimum required for the rating of the operations, which characterizes an additional opportunity for discretion by management in the composition of the LLP.

\subsection{Model for Identifying Determinants of Audit Quality.}

After identifying the audit quality proxy, the next step to test its determinants, based on the research hypotheses proposed in Section 3, is based on the estimation of model (4.3):

$$
\begin{gathered}
A Q_{i, t}=\beta_{0}+\beta_{i}+\beta_{1} A S_{i, t}+\beta_{2} C I_{i, t}+\beta_{3} S T_{i, t}+\beta_{4} L T_{i, t}+\beta_{5} A C_{i, t}+\beta_{6} H H_{t}+\beta_{7} L R_{t} \\
+\beta_{8}<R E_{t}>+\psi_{N}<C O N T_{i, t}>+\varepsilon_{i, t}
\end{gathered}
$$

where

$A Q_{i, t}$ is the quality of the audit performed in bank $i$ in period $t$, calculated in accordance with model (4.1);

$\mathrm{AS}_{\mathrm{i}, \mathrm{t}}$ is the degree of auditor specialization in the financial statements of bank $i$ at period $t$, in the Brazilian banking industry, calculated based on the total assets of the audited banks; $C I_{\mathrm{i}, \mathrm{t}}$ indicates the relative importance of bank $i$ for the auditor's client portfolio at period $t$, calculated according to the total assets of the banks (in the impossibility of accessing the compensation charged from clients);

$S T_{\mathrm{i}, \mathrm{t}}$ indicates that, at the time $t$ when the audit was conducted on bank $i$, the auditor-client relationship was of short term, assuming 1 for the audits performed during the first year of contract and 0 for the others;

$L T_{\mathrm{i}, \mathrm{t}}$ indicates that, at the time $t$ when the audit was conducted on bank $i$, the auditor-client relationship was of long term, assuming 1 for the audits performed after the sixth year of contract and 0 for the others ${ }^{4}$;

$A C_{\mathrm{i}, \mathrm{t}}$ indicates whether bank $i$ in period $t$ has an established Audit Committee, assuming 1 for entities that have the Committee and 0 for the others;

$\mathrm{HH}_{\mathrm{t}}$ reflects the degree of concentration of audit services in the Brazilian banking industry at period $t$, calculated through the Herfindahl-Hirschman Index ${ }^{5}$ and based on the volume of total assets of the banks;

$L R_{\mathrm{t}}$ translates the litigation risk against auditors at period $t$, calculated by the number of punitive administrative pro- ceedings against the audit firm judged by the $\mathrm{BCB}$ and the CVM divided by the number of firms that audited banks during the same period;

$\left\langle R E_{\mathrm{t}}\right\rangle$ is the vector of variables that measure the level of rigor of the regulatory environment of the audit market at period $t$. Three variables that assume dichotomous values (dummies) are considered: $R E_{0102}$ for audits conducted between 2001 and 2002; $R E_{0309}$ for audits conducted between 2003 and 2009, when the terms of CVM Instruction no. 381/2003 and CMN Resolution no. 3081/2003 came into force, establishing a series of requirements to ensure the independence and objectivity of auditors; and $R E_{1012}$ for audits conducted between 2010 and 2012, when the Federal Accounting Council (Conselho Federal de Contabilidade - CFC) resolution no. 1203/2009 came into force, establishing international auditing standards in Brazil;

$<C O N T_{\mathrm{i}, \mathrm{t}}>$ is the vector of control variables to bank $i$ in pe$\operatorname{riod} t$, used to optimize the empirical evidence of the tests and represents the following: the profitability level - return on assets $(R O A)$; the degree of capitalization - relationship between equity and total assets (CAP); nationality (NAT) - assumed as 1 for national banks and 0 for the others; the origin of the control capital (PUB) - assumed as 1 for banks under state control and 0 for the others; and the listing on the stock exchange (BOV) - assumed as 1 for banks listed on the BM\&FBovespa and 0 for the others.

\section{CALCULATION AND ANALYSIS OF RESULTS}

The empirical tests used data contained in the Quarterly Financial Information reports of commercial, multiple- -service and savings banks from 2001 to 2012, available on the $\mathrm{BCB}$ website. To ensure the robustness of the results, the 
panel data models were estimated by SUR (seemingly unrelated regression) fixed cross-sectional effects, which provides robust coefficients and standard errors, even in the presence of heteroskedasticity and contemporaneous correlations in the errors of the equations.

\subsection{Calculation of the Audit Quality Proxy.}

The first stage of the tests consists of calculating the audit quality proxy, from the application of equation (4.1), which depends on the identification of discretion in the process of constituting the LLP by the banks, based on model (4.2).

\begin{tabular}{|c|c|c|c|c|c|c|}
\hline \multicolumn{7}{|c|}{$\begin{aligned} L L P_{i, t} & =\beta_{0}+\beta_{i}+\beta_{1} \triangle L O A N_{i, t}+\beta_{2} N P L_{i, t-1}+\beta_{3} \Delta N P L_{i, t}+\beta_{4} L C O_{i, t}+\beta_{5} L L A_{i, t-1}+\beta_{6} I N T_{i, t} \\
& +\beta_{7} G D P_{t}+\psi_{1}<T Y P_{i, t}>+\psi_{2}<G E O_{i, t}>+\psi_{3}<M A T_{i, t}>+\psi_{4}<C N C_{i, t}>+\varepsilon_{i, t}\end{aligned}$} \\
\hline C & $\triangle L O A N$ & $N P L(-1)$ & $\triangle N P L$ & $\angle C O$ & $\operatorname{LLA}(-1)$ & INT \\
\hline 0.0111 & 0.0149 & 0.1481 & 0.1291 & 0.0517 & 0.0069 & 0.0047 \\
\hline$(0.000)$ & $(0.000)$ & $(0.000)$ & $(0.000)$ & $(0.003)$ & $(0.375)$ & (0.086) \\
\hline$* * *$ & $* * *$ & $* * *$ & $* * *$ & $* * *$ & & * \\
\hline$G D P$ & PRV & NRES & $S E$ & EXT & UP5Y & EX5Y \\
\hline-0.0193 & -0.0055 & -0.0041 & -0.0020 & -0.0035 & -0.0079 & -0.0035 \\
\hline$(0.000)$ & $(0.052)$ & $(0.187)$ & $(0.066)$ & $(0.011)$ & $(0.043)$ & $(0.000)$ \\
\hline$* * *$ & $* *$ & & * & $* *$ & $* *$ & $* * *$ \\
\hline \multicolumn{7}{|c|}{ Period: $2^{\text {nd }}$ quarter of 2001 to $4^{\text {th }}$ quarter of 2012} \\
\hline \multicolumn{2}{|c|}{ Observations } & 7.007 & $R^{2}:$ & 0.4896 & F Statistic: & 29.5869 \\
\hline Banks: & \multicolumn{2}{|c|}{208} & $d R^{2}:$ & 0.4730 & DW Statistic: & 1.7539 \\
\hline
\end{tabular}

Where $L L P$ is the loan loss provisions; $\triangle L O A N$ is the change in the value of loans; NPL the value of nonperforming loans; $\triangle N P L$ the change in the value of nonperforming loans; $L C O$ the net loan write-offs; $L L A$ is the loan loss allowance; INT is the of the loan portfolio's implicit interest rate; GDP is the rate of change of the Gross Domestic Product; $\angle T Y P>$ is a vector of variables representing the proportion of the loans portfolio distributed into public sector (PUB), private sector $(P R V)$, and non-residents (NRES); $\angle G E O>$ is a vector of variables representing the proportion of loans distributed in the geographic regions Southeast (SE), other regions of Brazil $(O R B)$, and overseas $(E X T) ;<M A T>$ is a vector of variables representing the proportion of loans portfolio distributed according to the maturity of loans - maturity up to 5 years (UP5Y), and maturity exceeding 5 years $(E X 5 Y)$; and $\angle C N C>$ is a vector of variables representing the proportion of loans portfolio distributed in the one hundred largest customers $(U P 1 H)$, and to other customers $(E X 1 H)$.

Significance of the parameters: $1 \%\left({ }^{* * *}\right), 5 \%\left({ }^{* *}\right)$ and $10 \%\left({ }^{*}\right)$.

The results shown in Table 1 are consistent with those calculated by Dantas et al. (2013), where detailed analyses on the behavior of the variables can be found. In the present study, the estimation of model (4.2) has the purpose of calculating the variable representing discretionary accruals (the error term), which will be the basis for calculating the audit quality proxy, through equation (4.1).

\subsection{Testing the Determinants of Audit Quality.}

After estimating the audit quality proxy, the next step is to conduct tests of association of this measure with variables representing auditor incentives, based on model (4.3), to test the research hypotheses.

\begin{tabular}{rrrrrrrr}
\hline \multicolumn{1}{c}{$A Q_{i, t}=\beta_{0}+\beta_{i}+\beta_{1} A S_{i, t}+\beta_{2} C I_{i, t}+\beta_{3} S T_{i, t}+\beta_{4} L T_{i, t}+\beta_{5} A C_{i, t}+\beta_{6} H H_{t}+\beta_{7} L R_{t}$} \\
$+\beta_{8}<R E>_{t}+\beta_{N}<C O N T>_{i, t}+\varepsilon_{i, t}$
\end{tabular}

Period: $3^{\text {rd }}$ quarter/2001 to $4^{\text {th }}$ quarter/2012 
continue

$A Q$ is the quality of the audit, calculated in accordance with model (4.1); $A S$ is the degree of auditor specialization in the Brazilian banking industry; $C l$ indicates the relative importance of bank i for the auditor's client portfolio; ST indicates that the auditor-client relationship was short term (first year of contract); $L T$ indicates that the auditor-client relationship was long term (after the sixth year of contract); $A C$ indicates whether the bank has an established Audit Committee; $\mathrm{HH}$ reflects the concentration degree of audit services in the Brazilian banking industry, calculated using the Herfindahl-Hirschman Index, with reference to the volume of total assets of the institutions; $L R$ translates the litigation risk against auditors, calculated by the number of punitive administrative proceedings against the auditors judged by the BCB and CVM; $<R E>$ is the vector of dummy variables that identify the different rigor levels of the regulatory environment of the audit market $-R E_{0102}$ for audits conducted between 2001 and 2002, $R E_{0309}$ for audits conducted between 2003 and 2009 and $R E_{1012}$ for audits conducted between 2010 and 2012 ; <CONT> is the vector of control variables, representing the return on assets (ROA), capitalization degree (CAP), nationality (NAT) of the banks, origin of the control capital (PUB) and that the bank is listed on the stock exchange (BOV). Significance of the parameters: $1 \%(* * *), 5 \%(* *)$ and $10 \%(*)$.

The compatibility of the results shown in Table 2 with the predictions of the research hypotheses reveals that, initially, no statistically significant relationship was found between audit quality and auditor specialization degree (AS) in the banking industry. Thus, hypothesis $H_{1}$, which predicted a positive relationship between these variables, considering that specialization would represent a broader understanding of accounting practices and trends in the segment, increasing the ability to assess evidence and identify problems in the statements, is not empirically confirmed. A potential explanation for this result may be that the most banks (92\% in 2012) are audited by one of the big four, perhaps making it impossible to identify a significant difference in relation to the audits conducted by companies with less participation in the banking market.

Regarding the client importance (CI) for the portfolio of the firm, the prediction of a negative relationship with audit quality was confirmed, supporting the premise expressed in hypothesis $\mathrm{H}_{2}$ that the greater economic dependence of the auditor in relation to a client makes the auditor more exposed to opportunistic demands by management - i.e., the auditor tends to compromise more with the demands of his most important clients.

Regarding the length of the contract between the auditor and financial institution (audit tenure), the research hypotheses predict that audit quality is compromised for the following: in short-term relationships, considering that the auditor does not know in depth about the risks of the business, in addition to being more prone to opportunistic arguments by management to attract the new client; and in long-term relationships, considering that the self-confidence of the auditor can reduce their skepticism or increase their ties with the client. The empirical tests conducted on the variable $S T$, which indicates the audits carried out during the first year of contract, reveal that they are not significantly different from those conducted during other periods, rejecting hypothesis $H_{3 \mathrm{~A}}$. In the case of the variable $L T$, which indicates the audits conducted after the sixth year of the contract, a negative and significant relationship was found with the audit quality proxy, confirming the predictions of hypothesis $H_{3 \mathrm{~B}}$.

The combination of these results - non-compromise of the audit quality when the auditor/client relationship is of short term and worsening of quality when the audit is conducted after the sixth year of the contract between the auditor and the client bank - offers evidence that reinforces the arguments of those who defend the institution of "auditor rotation".
Regarding the variable $A C$, representing the establishment of an Audit Committee, the empirical tests confirmed its positive and statistically significant relationship with audit quality, confirming the expectations of hypothesis $H_{4}$. This result is consistent with the role of the Audit Committee as an instrument of governance, particularly with regard to its relationship with the work of the independent auditors - it is expected that the establishment of the Committee creates conditions for the broader application of the auditor's professional skepticism, increasing the quality of the audits conducted.

Regarding the impact of the concentration of the audit market on the quality of the services provided, the empirical tests revealed no statistically significant relationship between the variables $H H$ and $A Q$, not confirming the predictions of $H_{5}$. This result reflects, in a way, the duality discussed by Ojo (2008), for whom concentration may have two distinct potential effects: the first effect shows that concentration encourages specialization, reducing the risk of distorted statements; and the second effect shows that greater competition (lower concentration) reduces the risk of an audit-dominant firm establishing practices that may encourage statements of poor quality. The lack of statistical significance in the tests also allows the conclusion that its alternative version, which would depend on a significant positive relationship between the variables under discussion, is corroborated.

According to the results, it is possible to infer that these two potential effects can act simultaneously, negating the significant statistical effects - i.e., there is no objective evidence of positive or negative effects of the concentration of audit activity on the quality of audits conducted within the SFN. This does not eliminate, however, other potential risks of a marked concentration, such as the impact on industry competition, the client choice process and the compensation of the auditors.

The impact of the litigation risk on the quality of the auditors' services is examined based on the hypothesis that the expectation of a punitive action creates economic and reputational incentives to act more restrictively in relation to the opportunistic behavior of management. Empirical tests showed a positive and statistically significant association between the variables $A Q$ and $L R$, corroborating hypothesis $H_{6}$ - i.e., at the times when more punitive administrative proceedings are judged by the $\mathrm{BCB}$ and $\mathrm{CVM}$ against the auditors, audits have a better quality. These results suggest, therefore, that auditors react to an environment with a greater risk of punishment with higher professional care when conducting the audits. It is 
noteworthy that, among the research hypotheses confirmed, $\mathrm{H}_{6}$ showed the lowest statistical significance.

The last research hypothesis evaluates the impact of a more rigorous regulatory environment on the quality of audits. For this purpose, the period considered in the study is divided into three sub-periods, according to the level of rigor of the professional norm in effect - from 2001 to $2002\left(R E_{0102}\right)$, from 2003 to $2009\left(R E_{0309}\right)$ and from 2010 to $2012\left(R E_{1012}\right)$. As it is assumed that these periods have increasing rigor levels, and the variables are of the dummy type, $R E_{0102}$ and $R E_{1012}$ are evaluated in the association tests with the audit quality proxies, for which negative and positive signs are expected, respectively, as a condition to the confirmation of the hypothesis.

The empirical tests in relation to the dependent variable showed the following: (i) a lack of statistical significance regarding the association with the variable $R E_{0102}$, rendering it impossible to state that the audits conducted between 2001 and 2002 - a period defined as less rigorous in reference to the regulatory environment - have a better or worse quality than those conducted between other periods; and (ii) a positive and statistically significant association with the variable $R E_{1012}$, demonstrating that the audits conducted between 2010 and 2012 - a period defined as more rigorous in reference to the regulatory environment - have a better quality than the others. The combination of these results, although not entirely consistent with hypothesis $H_{7}$, due to the lack of statistical significance for the variable $R E_{0102}$, provides evidence that greater regulatory rigor may be associated with audits of better quality.

Concerning the control variables, not objectively associated with incentives for the performance of auditors, incorporated with the purpose of improving the empirical evidence obtained in the tests in relation to the variables of interest, it was found that (i) institutions with a greater profitability level show less evidence of manipulation of financial information; (ii) the capitalization level of the entities does not affect the discretion degree of accruals in relation to the constitution of the LLP; (iii) banks whose control capital is of national origin have higher variations in the discretionary components of expenses with LLP, which suggests a greater possibility of manipulation; and (iv) there are no significant differences regarding the discretion level in the constitution of LLP between state and private banks and between institutions of capital listed on a stock exchange or not.

\subsection{Additional Tests in Relation to Auditor- Client Contract Length.}

To test the effect of the length of the contract between the auditor and financial institution on the audit quality, it was considered that the assumptions discussed in the literature on audit quality are compromised in short-term and long-term relationships - hypotheses $H_{3 \mathrm{~A}}$ and $H_{3 \mathrm{~B}}$, respectively - characterizing a non-linear relationship between the variables. Given the implicit subjectivity in defining what relationships would be of short and long term, as well as that, during the period considered in this study, there were three schemes of incentives for issues related to the extent of the relationship between auditors and financial institutions, mandatory rotation, suspension of the rotation and termination of the rotation, an additional test was performed by modifying the form of measuring the variable audit tenure.

For this purpose, the estimation of model (4.3) was replicated, replacing the variables $S T$ and $L T$ by the contract length variable $(\mathrm{CL})$, represented by the number of consecutive years of relationship between the audit company and financial institution. The results are shown in Table 3.

Table 3

\begin{tabular}{|c|c|c|c|c|c|c|c|}
\hline \multicolumn{8}{|c|}{$\begin{array}{c}A Q_{i, t}=\beta_{0}+\beta_{i}+\beta_{1} A S_{i, t}+\beta_{2} C I_{i, t}+\beta_{3} C L_{i, t}+\beta_{4} A C_{i, t}+\beta_{5} H H_{t}+\beta_{6} L R_{t} \\
+\beta_{7}<R E>_{t}+\beta_{N}<C O N T>_{i, t}+\varepsilon_{i, t}\end{array}$} \\
\hline$C$ & $A S$ & $\mathrm{Cl}$ & $C L$ & $A C$ & $H H$ & $L R$ & RE0102 \\
\hline-0.0067 & -0.0005 & -0.0023 & -0.0003 & 0.0011 & 0.0124 & 0.0036 & 0.0004 \\
\hline$(0.067)$ & $(0.682)$ & $(0.024)$ & $(0.000)$ & $(0.046)$ & $(0.223)$ & $(0.120)$ & $(0.623)$ \\
\hline * & & ** & & $* *$ & & & \\
\hline
\end{tabular}

\begin{tabular}{|c|c|c|c|c|c|}
\hline RE1012 & $R O A$ & CAP & $N A C$ & $P \cup B$ & $B O V$ \\
\hline 0.0013 & 0.0592 & -0.0022 & -0.0034 & -0.0015 & -0.0002 \\
\hline$(0.018)$ & $(0.000)$ & $(0.267)$ & $(0.003)$ & $(0.363)$ & $(0.718)$ \\
\hline$* *$ & $* * *$ & & $* * *$ & & \\
\hline
\end{tabular}

Period: $3^{\text {rd }}$ quarter/2001 to $4^{\text {th }}$ quarter/2012

\begin{tabular}{lrrrrr} 
Observ: & 6.661 & $R^{2}:$ & 0.2026 & F Stat: & 7.5428 \\
Banks: & 205 & adjusted $R^{2}$ & 0.1757 & DW Stat: \\
\hline
\end{tabular}

$\mathrm{AQ}$ is the quality of the audit; AS is the degree of auditor specialization on the Brazilian banking industry; $\mathrm{Cl}$ indicates the relative importance of bank i for the auditor's client portfolio; $C L$ indicates the contract length between the auditor and financial institution in number of years; $A C$ indicates whether bank $i$ has an established Audit Committee; $\mathrm{HH}$ reflects the concentration degree of audit services in the Brazilian banking industry, calculated using the Herfindahl-Hirschman Index, with reference to the volume of total assets of the institutions; $L R$ translates the litigation risk against auditors, calculated by the number of punitive administrative proceedings against the auditors judged by the BCB and the CVM; $<R E>$ is the vector of dummy variables that identify the different rigor level of the regulatory environment of the audit market- $R E_{0102}$ for audits conducted between 2001 and 2002, $R E_{0309}$ for audits conducted between 2003 and 2009, and $R E_{1012}$ for audits conducted between 2010 and 2012; <CONT> is the vector of control variables representing the following: the return on assets (ROA), capitalization degree (CAP), nationality (NAT), origin of the control capital (PUB) and that the bank is listed on the stock exchange (BOV). Significance of the parameters: $1 \%(* * *), 5 \%(* *)$ and $10 \%(*)$. 
The results initially demonstrate compatibility with those shown in Table 2. In general, all of the variables had the same signs and degree of significance despite the obvious residual changes in the coefficients. The difference was restricted to the variable litigation risk, $L R$, which, in the previous test, was significant at $10 \%$ and now has a p-value of 0.120 .

With specific regard to the audit tenure variable, the results showed an inverse statistically significant relationship between audit quality and auditor-client relationship length. These results are consistent with the empirical evidence of the original tests that indicated a negative relationship between the audit quality and long-term relationship between the audit firms and financial institutions. Thus, the results reinforce the evidence from the tests discussed in Section 5.2.

\subsection{Sensitivity Analysis.}

To validate the tests shown in Table 2, two additional tests were performed. In the first additional test, model (4.3) was estimated with fixed cross-sectional effects but without the use of control variables. In the second additional test, the model is estimated using the method of double fixed effects cross-section and time - which imposes the limitation of not considering the variables of temporal nature $\left(H H, L R, R E_{0102}\right.$ and $R E_{1012}$ ).

With minor variations in the coefficients and p-values, these additional tests have confirmed the results found in relation to the signs and statistical significance of the variables of interest, with one exception: the variable $L R$ is not statistically significant in the model estimated with fixed cross-sectional effects and without the control variables. These additional tests reinforce the reliability of the results presented in Table 2.

\section{FINAL THOUGHTS}

The reliability of financial information is an essential condition for the proper functioning of markets - in particular, the banking market - given that its institutions are subject to the systemic risk known as "bank run" in the case of suspicion by depositors. One of the aspects that can contribute to an environment of trust is the work of independent auditors, historically associated with the purpose of ensuring the credibility of the financial disclosure process. The review conducted by the auditors assumes an even greater significance considering that the preparation of financial information increasingly incorporates subjective aspects of professional judgment, facilitating potential opportunistic behavior by managers in the sense of concealing an occasionally unsatisfactory financial situation.

Considering this context, coupled with the lack of empirical evidence on the audits conducted in the banking markets, particularly in the Brazilian market, this study aimed to identify the determinants of the quality of audits of Brazilian banks conducted by independent auditors.

Empirical association tests of the audit quality proxy with the variables representing incentives for the performance of auditors have confirmed five of the seven research hypotheses, revealing that audit quality has the following relationships: negative with the level of client importance to the auditor; negative with the audits conducted after the sixth year of contract; positive with the establishment of an Audit Committee by the banks; positive with the judgment of punitive administrative proceedings against independent auditors; and positive with the level of rigor of the regulatory environment. Of the hypotheses tested, two were not confirmed empirically. The first of the latter predicted an association between audit quality and the degree of specialization of the auditor on the banking industry, and the second predicted that audit quality would have a negative relationship with the degree of concentration of audit activity within the SFN.

It is hoped that the identification of the determinant factors of the audit quality of Brazilian banks contributes to deepen the discussion concerning the role that independent auditors can perform for an environment of transparency and solidity of the financial system, including their role as a complementary or auxiliary supervisor. This study carries even greater importance when considering that the preparation of financial statements increasingly incorporates subjective aspects of professional judgment, possibly facilitating opportunistic behavior by management to conceal occasionally unsatisfactory financial situations.

Naturally, the study is subject to limitations. The main one is that the phenomenon under study, audit quality, is not an externally verifiable factor - at least simultaneously to its performance - imposing the need to use proxies. It should also be stressed that the models developed here and concomitant construction of the variables considered the specificities of the Brazilian banking market, not being applicable in another context without the necessary adaptations.

Thus, we suggest further research to test the validity of the models and research hypotheses in other settings, in addition to performing tests with other proxies of audit quality for the corroboration of the evidence obtained here and to identify other explanatory variables for the pattern of audit quality. 
Alali, F., \& Jaggi, B. (2010). Earnings versus capital ratios management: role of bank types and SFAS 114. Review of Quantitative Finance and Accounting, 36 (1), 105-132.

Almeida, J. E. F., \& Almeida, J. C. G. (2009). Auditoria e earnings management: um estudo empírico nas empresas abertas auditadas pelas big four e demais firmas de auditoria. Revista Contabilidade e Finanças, 20 (50), 62-74.

Amir, E., Guan, Y., \& Livine, G. (2010). Auditor independence and the cost of capital before and after Sarbanes-Oxley: the case of newly. issued public debt. European Accounting Review, 19 (4), 633-663.

Basel Committee on Banking Supervision. BCBS. (2008). External audit. quality and banking supervision. BIS. Recuperado em 13 novembro, 2013, de http://www.bis.org.

BBC Brasil. (2010). Relatório: Lehman Brothers escondeu dívidas antes de quebrar. Recuperado em 30 junho, 2013; de http://www.bbc.co.uk/ portuguese/.

Bedard, J. C., \& Johnstone, K. M. (2004). Earnings manipulation risk, corporate governance risk, and auditors planning and pricing decisions. The Accounting Review, 79 (2), 277-304.

Behn, B. K., Choi, J., \& Kang, T. (2008). Audit quality and properties of analyst earnings forecasts. The Accounting Review, 83 (2), 327-349.

Bernard, V. L., \& Skinner, D. J. (1996). What motivates managers' choice of discretionary accruals? Journal of Accounting and Economics, 22 (1-3), 313-325.

Besacier, N. G., Hottegindre, G., \& Fine-Falcy, S. (2011 April). The impact of recent regulatory changes on perceived audit quality as viewed by French auditors. Proceedings of the European Accounting Association, Annual Meeting, Rome, Italy, 34.

Borgeth, V. M. C. (2007). SOX: Entendendo a Lei Sarbanes-Oxley. São Paulo: Thomson Learning.

Braunbeck, G. O. (2010). Determinantes da qualidade das auditorias independentes no Brasil. Tese de doutorado, Universidade de São Paulo, São Paúlo, SP, Brasil.

Carcello, J. V., Bedard, J. C., \& Hermanson, D. R. (2009). Responses of the American Accounting Associations Tracking Team to the recommendations of the Advisory Committee on the Auditing Profession. Accounting Horizons, 23 (1), 69-84.

Carcello, J. V., \& Nagy, A. (2004). Client size, auditor specialization and fraudulent financial reporting. Managerial Auditing Journal, 19 (5), 651-668.

Chambers, D., \& Payne, J. (2008). Audit quality and the accrual anomaly. SSRN Working Papers. Recuperado em 20 dezembro, 2013, de http:// papers.ssrn.com.

Coffee J. C., Jr. (2004). What caused Enron? A capsule social and economic history of the 1990's. Cornell Law Review, 89 (2), 269-309.

Cohen, D. A., Dey, A., \& Lys, T. Z. (2008). Real and accrual-based earnings management in the pre- and post-Sarbanes-Oxley periods. The Accounting Review, 83 (3), 757-787.

Dang, L. (2004). Assessing actual audit quality. Thesis Ph.D, Drexel University, Philadelphia, Pennsylvania, USA.

Dantas, J. A., Medeiros, O. R., \& Lustosa, P. R. B. (2013). The role of economic variables and credit portfolio attributes for estimating discretionary loan loss provisions in Brazilian banks. Brazilian Business Review, 10 (4), 65-90.

Dao, M., Mishra, S., \& Raghunandan, K. (2008). Auditor tenure and shareholder ratification of the auditor. Accounting Horizons, 22 (3), 297-314

DeAngelo, L. E. (1981). Auditor size and audit quality. Journal of Accounting and Economics, 3 (1), 183-199.

DeFond, M. L., Wong, T. J., \& Li, S. (1999). The impact of improved auditor independence on audit market concentration in China. Journal of Accounting and Economics, 28 (3), 269-305.

Demski, J. S. (2004). Endogenous expectations. The Accounting Review, 79 (2), 519-539.

Dye, R. A. (1993). Auditing standards, legal liability, and auditor wealth. The Journal of Political Economy, 101 (5), 887-914.

Feldman, D. A., \& Read, W. J. (2010). Auditor conservatism after Enron. Auditing: A Journal of Practice \& Theory, 29 (1), 267-279.

Geiger, M. A., \& Raghunandan, K. (2002). Auditor tenure and audit reporting failures. Auditing: A Journal of Practice and Theory, 21 (1), 67-78.

Ghosh, A., \&.Moon, D. (2005). Auditor tenure and perceptions of audit quality. The Accounting Review, 80 (2), 585-612.

Government Accountability Office. GAO. (2003). Public accounting firms: mandated study on consolidation and competition. Recuperado em 27 dezembro, 2013, de http://www.gao.gov.
Government Accountability Office. GAO. (2008). Audits of public companies: continued concentration in audit market for large public companies not call for immediate Action. Recuperado em 27 dezembro, 2013, de http://www.gao.gov.

Gu, Z., Lee, C. W. J., \& Rosett, J. G. (2005). What determines the variability of accounting accruals? Review of Quantitative Finance and Accounting, 24 (3), 313-334.

Gul, F. A., Fung, S. Y., \& Bikki, J. (2009)..Earnings quality: some evidence on the role of auditor tenure and auditors' industry expertise. Journal of Accounting and Economics, 47 (3), 265-287.

Heninger, W. G. (2001). The association between auditor litigation and abnormal accruals. The Accounting Review, 76 (1), 111-126.

Kallapur, S., Sankaraguruswamy, S., \& Zang, Y. (2010). Audit market concentration and audit quality. SSRN Working Papers. Recuperado em 5 dezembro, 2012, de http://papers.ssrn.com.

Kanagaretnam, K., Krishnan, G., \& Lobo, G.J. (2009). Is the market valuation of banks' loan loss provision conditional on auditor reputation? Journal of Banking and Finance, 33 (6), 1039-1047.

Kanagaretnam, K., Krishnan, G., \& Lobo, G.J. (2010). An empirical analysis of auditor independence in the banking industry. The Accounting Review, 85 (6), 2011-2046.

Kanagaretnam, K., Lim, C. Y., \& Lobo, G. J. (2010). Auditor reputation and earnings management: international evidence from the banking industry. Journal of Banking.and Finance, 34 (10), 2318-2327.

Kanagaretnam, K., Lobo, G. J., \& Mathieu, R. (2003). Managerial incentives for income smoothing through bank loan loss provision. Review of Quantitative Finance and Accounting, 20 (1), 63-80.

Krishnan, G. V. (2005). The association between Big 6 auditor industry expertise and the asymmetric timeliness of earnings. Journal of Accounting, Auditing and Finance, 20 (3), 209-228.

Lam, S., \& Chang, S. (1994). Auditor service quality and auditor size: evidence from initial public offerings in Singapore. Journal of International Accounting Auditing and Taxation, 3 (1), 103-114.

Lys, T., \& Watts, R. L. (1994). Lawsuits against auditors: Journal of Accounting Research, 32 (Supplement), 65-93.

Magilke, M. J., Mayhew, B. W., \& Pike, J.E. (2009). Are independent audit committee members objective? Experimental evidence. The Accounting Review, 84 (6), 1959-1981:

Manita, R. (2009 junho). The quality of audit process: proposal of scaling measure. Anais do Congresso IAAER-ANPCONT, São Paulo, SP, Brasil, 3.

Martinez, A. L., \& Reis, G. M: R. (2010 julho). Rodízio de auditores e o gerenciamento de resultados. Anais do Congresso USP de Controladoria e Contabilidade, São Paulo, SP, Brasil, 10.

Múrcia, F. D., \& Borba, J. A. (2007). Estrutura para detecção do risco de fraude nas demonstrações contábeis: mapeando o ambiente fraudulento. Brazilian Business Review, 4 (3), 171-190.

Nagy, A. L. (2005). Mandatory audit firm turnover, financial reporting quality, and client bargaining power: the case of Arthur Andersen Accounting Horizons, 19 (2), 51-69.

Nelson, M. W., Elliott, J., \& Tarpley, R. L. (2002). Evidence from auditors about manager's and auditor's earnings management decisions. The Accounting Review, 77 (Sup.), 175-202.

Newman, D. P., Patterson, E. R., \& Smith, J. R. (2005). The role of auditing in investor protection. The Accounting Review, 80 (1), 289-313.

Ojo, M. (2006). Auditor independence - its importance to the external auditor's role in banking regulation and supervision. SSRN Working Papers. Recuperado em 2 abril, 2013, de http://papers.ssrn.com.

Ojo, M. (2008). The role of the external auditor in the regulation and supervision of the UK banking system. Journal of Corporate Ownership and Control, 5 (4), 1-21.

Oliveira, A. Q., \& Santos, N. M. B. F. (2007). Rodízio de firmas de auditoria: a experiência brasileira e as conclusões do mercado. Revista Contabilidade \& Finanças, 18 (45), 91-100.

Pae, S., \& Yoo, S. (2001). Strategic interaction in auditing: an analysis of auditors' legal liability, internal control system quality, and audit effort. The Accounting Review, 76 (3), 333-356.

Palmrose, Z. V. (1988). An analysis of auditor litigation and audit service quality. The Accounting Review, 64 (1), 55-73.

Resolução do Conselho Monetário Nacional n. 2.682, de 21 de dezembro de 1999. (1999). Dispõe sobre critérios de classificação das operações de crédito e regras para constituição de provisão para créditos de liquidação duvidosa. Recuperado de: http://www.bcb.gov.br/pre/. normativos/res/1999/pdf/res_2682_v2_L.pdf>.

Romanus, R. N., Maher, J. J., \& Fleming, D. M. (2008). Auditor industry specialization, auditor changes, and accounting restatements. Accounting Horizons, 22 (4), 389-413. 
Sanderson, R. (2010). Domínio das quatro grandes volta â pauta. Publicado originalmente no Financial Times, Londres. Jornal Valor Econômico. Recuperado de http://www.valor.com.br/arquivo/839539/ dominio-das-quatro-grandes-volta-pauta.

Santos, F. P. (2008). A relação entre o parecer de auditoria e a troca de auditores: uma investigação nas instituições financeiras. Dissertação de mestrado, Fundação Getúlio Vargas, Rio de Janeiro, RJ, Brasil.

Schipper, K. (1989). Commentary on earnings management. Accounting Horizons, 3 (1), 9i-102.

Silva, A. G., \& Robles Júnior, A. (2008). Os impactos na atividade de auditoria independente com a introdução da lei Sarbanes-Oxley. Revista Contabilidade e Finanças, 19 (48), 112-127.

Silva, J. O., \& Bezerra, F. A. (2010). Análise do gerenciamento de resultados e o rodízio de firmas de auditoria nas empresas de capital aberto. Revista Brasileira de Gestão de Negócios, 12 (36), 304-321.

Siregar, S. V., Amarullah, F., Wibowo, A., \& Anggraita, V. (2012). Audit tenure, auditor rotation, and audit quality: the case of Indonesia. Asian Journal of Business and Accounting, 5 (1), 55-74.
Smith, L. M. (2006). Audit committee effectiveness: did the blue ribbon committee recommendations make a difference? Int. J. Accounting, Auditing and Performance Evaluation, 3 (2), 240-251.

Souza, C. M. (2007). Accounting quality versus auditor choice under strong tax-gaap conformity: the case of Brazil. Revista Contabilidade e Finanças, 18 (43), 84-96.

Talley, E: L. (2006). Sarbanes-Oxley accounting issues: cataclysmic liability risk among big four auditorș. Columbia Law Review, 106 (1), 1641-1697.

Teoh, S. H., \& Wong, T. J. (1993). Perceived auditor quality and the earnings response coefficient. The Accounting Review, 68 (2), 346-366.

Venkataraman, R., Weber, J. P., \& Willenborg, M. (2008). Litigation risk, audit quality, and audit fees: evidence from initial public offerings. The Accounting Review, 83 (5), 1315-1345.

Vincent, L. et al. (2003). Evaluating concepts -based vs. rules-based approaches to standard setting. Accounting Horizons, 17 (1), 73-89.

Zagonov, M. (2011 April). Audit quality and bank risk under heterogeneous regulations. Proceedings of the European Accounting Association, Annual Meeting, Rome, Italy, 34. 